\title{
NADAR, Charles Baudelaire intimo: il poeta vergine
}

\section{Andrea Schellino}

\section{(2) OpenEdition \\ Journals}

\section{Edizione digitale}

URL: http://journals.openedition.org/studifrancesi/15666

DOI: 10.4000/studifrancesi. 15666

ISSN: 2427-5856

\section{Editore}

Rosenberg \& Sellier

\section{Edizione cartacea}

Data di pubblicazione: 1 décembre 2018

Paginazione: 517

ISSN: 0039-2944

\section{Notizia bibliografica digitale}

Andrea Schellino, «NADAR, Charles Baudelaire intimo: il poeta vergine», Studi Francesi [Online], 186 (LXII I

III) | 2018, online dal 01 janvier 2019, consultato il 05 janvier 2021. URL: http://

journals.openedition.org/studifrancesi/15666 ; DOI: https://doi.org/10.4000/studifrancesi. 15666

Questo documento è stato generato automaticamente il 5 janvier 2021.

\section{(c) (†)}

Studi Francesi è distribuita con Licenza Creative Commons Attribuzione - Non commerciale - Non opere derivate 4.0 Internazionale. 


\title{
NADAR, Charles Baudelaire intimo: il poeta vergine
}

\author{
Andrea Schellino
}

\section{NOTIZIA}

NADAR, Charles Baudelaire intimo: il poeta vergine, a cura di Ida Merello, traduzione di Albino Crovetto, Torino, Robin, coll. Biblioteca del vascello, 2017, 87 pp.

1 Nadar, pseudonimo di Félix Tournachon, è oggi principalmente ricordato per essere stato uno dei pionieri della fotografia. Eccellente caricaturista, si è altresì distinto come aeronauta e come scrittore. Ida Merello ha il merito di presentare la prima traduzione italiana, ad opera di Albino Crovetto, del Charles Baudelaire intime: le poète vierge di Nadar, pubblicato nel 1911 presso Auguste Blaizot. Benché i ricordi dell'artista ormai nonagenario siano incerti, e le tesi contestabili, il volumetto è una testimonianza preziosa: non soltanto raccoglie diversi documenti allora inediti su Baudelaire, ma propone un affresco affettuoso della vita letteraria parigina della metà dell'Ottocento. 